\title{
Structure and Functions of Mental Attitude in the Formation of the Value System of the Professional Musician
}

\author{
Valeriy Georgievich Mozgot \\ Rashid Dumalichevich Khunagov \\ Svetlana Anatolyevna Mozgot
}

Federal State Budget Institution of Higher Professional Education «Adyghe State University» (ASU) 385000, Maikop, street Pervomayskaya, 208, Russian Federation; Email: nisadgu@yandex.ru

\section{Doi:10.5901/mjss.2015.v6n5s1p488}

\section{Abstract}

At the modern level of the psychology development the concept of "attitude" attracts attention of scientists in the various fields. It is actively developed in the psychology, sociology and a number of other sciences; however it has been characterized by certain terminological uncertainty up to now. In the works of the domestic and foreign scientists F.V. Bassin, S.K. Bondyreva, I. Inesco, I. Solbes, W. Swami, D.N. Uznadze, D.I. Feldstein mental attitude (einstellung, bewustseinlage, attitude, etc.) is defined as the subject's readiness, inclination, disposition to the definite activity providing the purposeful nature of its development, and implementation. The essence of the problem is that in spite of considerable number of the investigations concerning the psychology of attitude in the various kinds of activity, it remains terra incognita in many respects. Thus, its role in the context of the development of various human activities in the sphere of music, art looks underdeveloped. And the role of attitude as a bridge between the theoretical and practical activities in the consciousness of the personality of the instrumentalist musician is even more obscure. This paper is aimed at determining structure and functions of mental attitude in the formation of the professional musician's value system. The following methods were used in the work: perception, performance of musical pieces, the creation of "projective situations" in the educational activity of the students, activity product analysis. The attitude and musical values make psychical plan for manifestation of the peculiarities of aesthetic perception of the modern young person in the sphere of music. The mechanism of action of the mental attitude develops as the readiness, disposition to perform, perceive and analyze musical and aesthetic works. Its operation is characterized by close unity of the conscious (realized) and the unconscious (subconscious). Three stages (phases) are distinguished in the attitude functioning: the subconscious, the transient phase, the conscious. Stage "switch-on" sequence of involvement may differ: both from the unconscious ("upwards") to the conscious, and from the conscious ("downwards") to the unconscious. The alternation of stages is determined by the certain situation, the task set out for the performer, the spectator, the listener. The totality of the established aesthetic values makes the axis of musical and aesthetic consciousness as the mentality of the person in the field of musical art. It does determine the conditions and peculiarities of the process progress of musical communication, perception and experience of music, manifested in the relevant judgments, estimates, opinions and ideals based on the mental attitude.

Keywords: mental attitude, aesthetic values, the unconscious, students, musical activity.

\section{Introduction}

When referring to the professional activity of the person in any sphere it is particularly noticeable that this activity is always a structure of relations (V.N. Myasishchev). Musical activity is not exclusion in this sense. The attitude acts here as a structure of relations that encourages a person to the activity exhibited thereby, in its activities and behavior (Prangishvili, 1967). At the same time the personality's value system is formed as well. However, the system of aesthetic values has no direct exit to the behavior. It is the attitude that plays the role of a mediator between the system of aesthetic values and behavior. It acts as a regulator of human behavior not only in the sphere of art, but also in the real life. Thus, depending on the comprehension of value senses of human behavior in the world of musical phenomena and works of art, a mental attitude appears in the listener, composer, musical critic or educator to carry out their own actions in the sphere art (Uznadze, 2014, 1964) Moreover, this action is always aesthetically colored. In opinion of I. Bzhalava, mental attitude appear in such action as "...the dynamic state of the subject's aesthetic taste, where it expresses certain orientation, thingness of our perception, imaginations, their sensually given content" (Bzhalava, 1969).

On the other hand, the aesthetic sphere of personality is a material of various art events and pieces of music on 
the field of which the action of the attitude unfolds. Sensory information received from the aesthetic feelings, views, ideals, taste, and artistic experience is present in the "minimized" form in this attitude. Interaction with the orientation of aesthetic values indicates one of the functions of mental attitude to exhibit, highlight the norms, ideals, beliefs that exist in the aesthetic consciousness of the person.

The mechanism of action of the attitude proceeds as follows: it directs the subject's attention on the object (a piece of music), and consciousness implements all sides of "attention" in the various kinds of musical activity: perception, analysis, music-making, performance, etc. The attitude combines, at first glance, absolutely different (multi-ordinal) factors: aesthetic mentality of the subject, his or her social group, the society in general, and the personality's need for creative fulfillment and manifestation of musical activity in the concrete form. However the personalistic and social elements are values not so much detached from each other. When considering the process of the mechanism of attitude action during preparation of the performing musician, it is not difficult to notice how verbal accentuation triggers the appropriate attitude in him or her. It is built in the content of his or her musical and aesthetic value system (norms, beliefs, opinions, estimates, ideal) and further on is inevitably expressed in both performance and in perception of musical pieces and other works of art.

Approach to studying the mental attitude structure is implemented by us at two levels of the psychical (the conscious and the unconscious), with clear distinction between the actual perception and verbal effect. This distinction gives opportunity to show the impact of internal special psychological requisite and external social factors forming the personality of the musician. Modern psychology states the unconscious, constancy, stability, irradiation, generalization in this process (the development of attitude) as characteristics of the entire activity of the individuality in the art. In the work on formation of the personality of future performing musicians our practice has shown that it is necessary to include both the consciousness and the creative powers of the subconscious (Mozgot, 2009).

Psychology distinguishes the procedure of group creative process among the actual forms of such activity, for example, the brainstorming strategy of Alex Osborn. It creates all conditions for activation of the subconscious in students: effects of group dynamics and psychic contagion; techniques of association and spontaneous conjecturing; prohibitions on the preliminary critics; selecting a group of "idea hamsters". For soloist musicians such procedure is not quite good, but it is unquestionably efficient for on-stage performance groups- musical theatres, orchestras, vocal and instrumental ensembles, in particular, at the first stage of works with the piece of music when its new interpretation is being born.

These techniques remove the dictate of logics of musical perception and performance well enough, producing thereby free play of the subconscious. The experience of group perception and performance of musical pieces shows that a holistic functional mechanism of the subconscious reveals in the form of individual abilities (Bochkarev, 1989; Tarasov, 1979, 1991; Mozgot, 2009). There are two stages observed in the action of the holistic mechanism of psychological attitude: the weakening of the action of the normal controls (logic, rules, prohibitions) and application of the free flow of hypotheses associations.

The objectives of the first phase are sometimes achieved by not entirely conventional means - not only by changing attitudes but also by the impact of other means on the brain (drugs, psychological means, hypnosis, etc.) These experiments were conducted in the US by a group of scientists under the direction of Stanislav Grof. They identified four levels of the psyche: the sensory barrier; the recollective-biographical unconscious; perinatal experience (experience of "new birth"); transpersonal sphere. In the normal state (unaltered state of the consciousness - V.M.), the last three levels are blocked by a powerful psychic protection of the personality. But if its action is weakened by psychedelic drugs, the subconscious powers demonstrate the multidimensional (holonomic) way of thinking.

The author of this article has observed repeatedly the sessions of the known psychotherapist V. Raykov, where many of the subjects who had no musical education, created under hypnosis very interesting and high-skilled pieces of music. There is no doubt that the mechanism acting as a barrier on the way of idea from the subconscious to the conscious realm was blocked. To apply or not to apply such a way in order to activate the features of aesthetic perception of contemporary musicians is a special question. But the fact that it contains its own advantages - images created by the subconscious mind differ in refined whimsicality - is fairly indicative.

The concept of $\mathrm{P}$. Simonov has made a significant contribution to the development of the theory of mental attitude. In this concept the mental attitude becomes one of the indicators of the unconscious sphere activity. It involves the consciousness not only as an area of the conscious, but also of the unconscious, including manifestations of the subconscious and super-consciousness. According to the developments of the scientist, the subconscious works at the level of automatism, and the super-consciousness embodies the spiritual creativity of the person. Thus, intuitive hypotheses appear to be protected from the burden of experience and dogmatic mind control by its unconscious form. Only after specific assumptions they are logically discarded (Simonov, 1985). 
Thus, in the initial stages of the musician's work on the piece of music his methods are conscious. But, after setting out the problem of interpretation and trying multiple conscious attempts to find a method for solving, the solution itself usually comes during work of the subconscious (super-consciousness). If such a sequence is quite legitimate for the theoretical science with high level of rationalistic element, the practice of musical education and training does not require including the work of the subconscious mechanism, and the consciousness itself creates a wide field for the action of the unconscious, where informative elements of aesthetic space of psyche occur and are formalized.

Within the conventional scheme (the consciousness - the problem - the unconscious) a model of sensory and rational structure of intuition develops. Here the logic in the aesthetic perception foregoes the unconscious processes, and somehow completes it. Thus, as A. Kudryashov believes, the synthesis of concepts and visual representations takes place at the unconscious level, because the consciousness manifests itself in notions or in sensory models. (Kudryashov, 1988).

One can agree with the proposed point of view on the action of the unconscious in the mechanism of musical performance and creativity with one caveat - between the conscious and subconscious some transient phase should be implemented (or exist), which clearly "separates" these spheres of the human psyche, "disabling" one and actuating another. And all this takes place within a single mechanism of functional structure of the action as a whole, in our case, the aesthetic perception and/or performance of a musical piece.

However, another alternative is possible. On condition of the uttermost convergence of the conscious purposeful nature and the appropriate repression, the dominants of the interpretation search by the performer of the musical piece are associated with the functional asymmetry of the brain, that is, its division into the left - "logical-mathematical" and the right - "intuitive sensory" hemispheres. When a new interpretation or arrangement of a musical piece goes wrong, after numerous "left hemisphere" attempts to follow the procedure the search somehow "goes down" to the subconscious. At this moment the right hemisphere starts working with its developed fantasy and imagination. And after finding a satisfactory solution to the problem, the option found again "goes up" into the left hemisphere realm with the aim of logic verification and validation of the accepted hypothesis-association or the flow of associations by the consciousness. (Mozgot, 2012).

Thus, in the aesthetic sphere a holistic field of the conscious and the unconscious in the personality's mentality becomes a certain way of touch with reality, with the world of musical and artistic works. (Bassin, 1968).

Although to fix this situation is not as simple as it seems at first glance. Hence, for example, a need arises to distinguish between the experience, musical perception patterns and attitude in the perception of musical pieces. Due to the fact that such forms as the perception and performance of pieces of music prevail in the musical activity of a human, let us consider the effect of attitude on the process of music perception.

Among them, the scientists identified general and particular types of attitude, and the external and internal kinds; the attitude - disposition to the world of artistic images of the work as "a special reality", etc.

Without analyzing in detail the effect of these attitudes (since this would require a significant expansion of the scope of the article), we note the most significant. Firstly, they all do not act separately, each by itself, but in close contact, even "intertwining" with each other. Their another feature is that they are the products of aesthetic consciousness of the listener, spectator, affecting, in turn, their development and change. Next feature is reliance on the personality's thesaurus, artistic experience of perception and performance of musical pieces.

Appeal to the general and particular psychological attitude leads to the conclusion that their actions are complementary. General (objective) attitude determines the role of a social factor and its "specific gravity" in the individual world of aesthetic values, including the value orientations of the person in music, art. Particular (subjective) attitude specifies the effect of general attitude, setting up the performing musician, the listener, the music critic on the perception of "wavelength" of a musical piece, its style, genre, defining the place of this piece in the creative work of this or that composer, the composer's creative work in the context of the epoch, etc.

The relationship between the system of aesthetic values and the attitude looks like the interaction between the public and the individual in the psyche of the composer's, performer's personality. The attitude has a different effect on the nature of human consciousness in the world of music, but the person has no way to "escape" from the power of the attitude, a special field of attraction in which this person grows, spiritually forms and actually functions.

The content of the system of aesthetic orientation of a person as a social-psychological phenomenon and an individual phenomenon is always a product of relations on the basis of the attitude. Subordinance of the individual system of aesthetic values to the value system adopted in this society is realized through the mechanism of suggestion (as the shortest route). It is particularly noticeable in the impact on the listeners, the spectators by means of modern mass media technologies and popular rock music. Such impact occurs by interlacing the basic metrical and rhythmical beats coinciding with the rhythm of the heart rate and by creating "maximum stretched time" that immerses a person in the 
stream of consciousness, such as in Eastern meditative music (the compositions of the Mahavishnu Orchestra, Ravi Shankar, etc.)

The ability of the mental attitude to focus on a particular style or genre of music creates not only readiness for its perception and performance, but also makes it possible to integrate into a new subculture and become "at home" amongst the peers. This capacity emerges in one individual, and in the social group to which he or she belongs (pupils, students). Here, the attitude acts as a focus of today's youth on the specific art objects, pieces of music and other art forms, musical and aesthetic values.

Modern understanding of the values is that they exist in any association of people. These values are stored in the minds of members of a particular group, and they appear and manifest themselves in the interaction with the current reality. By entering into relationship with people, pieces of music, the person focuses on the aesthetic objects and evaluates the latter as essential or unessential for themselves (Purvis, 2008; Solbes, 2010; Vartanova, 2007).

\section{Methods}

In our long-continued practical work with students from various faculties of the Adyghe State University (Institute of Arts, Faculty of Pedagogy and Psychology) methods of creating a positive psychological attitude to play in the concerts, at the exams or final test were used. In addition, more than a quarter-century's experience of introducing observation by the author of this article into the practice of educational activity of students of different specialties (future music teachers, primary school teachers, economists, etc.) and application of the method of creating a "projective situation" in the educational activity convincingly testified various value orientations in students, boys and girls. Thus, whereas young men, according to our observations, look mostly for the possibilities for expression and self-affirmation of themselves in the labor and training activities (and, at times, simultaneously in labor-training), the girls focus in addition on the external positive response of the social environment. Two groups of needs are particularly distinguished for this age group: the need for the new experience, cognition and the need for professional recognition (Mozgot, 2012).

\section{Results and Discussion}

The process of the studying relationships of concepts of "psychological attitude" and "aesthetic values" in the person's consciousness required us to transfer theoretical considerations into practical plane. These concepts were considered by us as applied to the age group of 18-27 years, because these are the main age ranges of contemporary young students. The latter conditioned the correlation of the concept of "aesthetic values" with the psychological characteristics of this age group. Under the musical and aesthetic values of contemporary college students, we understood the psychological experience of senses, meanings of musical pieces, bearing in mind the aesthetic preferences of a young person, providing for the social forecast and later for adjustment of behavior of youth groups and trends.

Formation of the system of musical and aesthetic values of the personality at this age has a number of peculiarities. They result from the fact that, firstly, physical development of the person is completed; secondly, the social situation is changed. Students are looking for a role model. Moreover, they clearly capture the unprepared teacher, notice his "errors" in the professionalism, aesthetic culture, authoritarianism, etc.

Exaggeration of their own forces in a number of the participants is quite clearly visible in the student group. There is also a kind of "transfer" of academic performance in school to other objects: many young men think that if they learn well in certain disciplines, they are quite competent in other subjects of the specialty.

A new level of mental development at this age manifests itself also in intolerance for weaknesses of others, requirements for other people to be accurate in every detail. At this age, close people quite often get very specific moral assessment of the young people (Kon, 1987, 1978; Bondyreva, Kolesov, 2007; Feldstein, 2012, 2005). The special dynamics of the senses under the influence of social and psychological factors is inherent in them. It is not surprisingly that this is reflected in their aesthetic activity.

The aesthetic outlook and aesthetic ideals of the modern young students manifest the traits of isolation, differences both from the world of children and from the world of adults, and at the same time, the features of peculiar assimilation in the social group, standardization - conformity. This, in turn, creates a psychological basis (as a set of mental attitudes) for the appearance of "universal" musical values in them: the tastes, fashion, hobbies. Identification of ways of formation of the needs and interests, feelings, viewpoints and tastes of a young person paints also a vivid picture of the changes of the entire system of aesthetic values, in comparison with the value system of 10-15 years ago.

Being enthusiastically engaged in subjects of their future profession, students creatively refract the requirements of social, in particular, the musical environment through the system of their aesthetic values. At the same time, there are 
often contradictions in the behavior of students, which are manifested, on the one hand, in an effort to follow their own moral freedom, and on the other hand, in the need to comply with ethical requirements. In this context, the opinion of I.S. Kon with regard to the attitude to the fact from which gender originates the "self-image" holds true.

French psychologist René Zazzo notes that psychological retrospective description of their age vary significantly in boys and girls. The former have more dynamic life stories, more stringent attributes, while the latter show much more attention to the world of the senses (Kon, 1978).

The need for knowledge leads the students to the increased interest in learning, future profession, preparing for the activity itself. In parallel, the scope of communication is also expanding. The subject of communication, attitudes and values is determined by the problems of personality, finding their place in the world and interaction with it. At the same time, contemporary students constantly find themselves in situations that require specific solutions (to listen, to perform or not to perform specific pieces of music, to attend or not to attend certain lectures, seminars, etc.) So they quite naturally have a need to review and evaluate, choose possible alternatives in determining the future of professional values (values of the profession), views of life. Those values are still unsettled, insufficiently realized and interiorized. The development of the entire field of aesthetic values proceeds as a dual process: on the one hand, as the attitude of young people to assimilate themselves with the surrounding persons, but on the other, as their mental attitude to distinguish themselves as a result of isolation (and all this, sometimes occurs simultaneously.

The desire to isolate themselves is reflected mainly in the "withdrawal" and in seclusion. Here, boys and girls "escape to the dreams" about their future life, work, friends, etc. They create an array of alleged "projective" situations in which they kind of reproduce their behavior related to specific people, facts, phenomena of reality. Concurrently, their aesthetic ideals begin to crystallize. They may be focused on the public (although this is observed much rarer in the situation of the early 10-ies of the new century than 10 - 15 years ago), and the individual values.

\section{Summary}

Thus, the leading values in modern young students are the desire to achieve success in communicating with their peers, in getting the knowledge, in the training of future profession. The totality of the existing aesthetic values makes the axis of the musical and aesthetic consciousness as the person's mentality in the field of musical art. It is this totality that determines the conditions and peculiarities of the process of musical communication, perception and experience of music manifested in the relevant judgments, estimates, opinions, ideals on the basis of mental attitude.

\section{Conclusions}

Mental attitude is a complicated dynamic structure in the human psyche. The mechanism of its action is based on immanent interaction of the conscious and the unconscious, of the internal and external factors affecting the norms, suggestions, beliefs and the human behavior in general.

Thus, mental attitude is the major substrate influencing the formation of the system of the personality's aesthetic values. The whole process of the personality's behavior and activities in the sphere of art becomes the field of continuous emergence and transformation of the attitudes. The psychological attitude action takes place within a single functional structure of action as a whole. With regard to musical activity it is a process of actualization of impressions, emotions, artistic associations, derived from perception, performance, essays, criticism, etc.

The attitude and musical values constitute the psychological plan for development of the peculiarities of aesthetic perception of the modern young person in the sphere of music. The mechanism of action of mental attitude proceeds as readiness, predisposition to perform, perceive and analyze musical and aesthetic pieces. His work is characterized by the close unity of the conscious (supraliminal) and the unconscious (subconscious). There are three stages (phases) in the attitude functioning: the subconscious, the transient phase and the conscious. A sequence of stage "switch-on" involvement may be different: both from the unconscious ("upwards") to the conscious and from the conscious ("downwards") to the unconscious. The alternation of stages is determined by the certain situation, the task set out for the performer, the spectator, the listener.

The totality of the existing aesthetic values makes the axis of the musical and aesthetic consciousness as the person's mentality in the field of musical art. It is this totality that determines the conditions and peculiarities of the process of musical communication, perception and experience of music manifested in the relevant judgments, estimates, opinions, ideals on the basis of mental attitude.

The real contradiction of the individual's values and values of a particular social group makes it possible to identify certain specific facets of aesthetic consciousness of society in general. The differences between them in contemporary 
society lead often to the open polarization of views, interests, ideals of people in direct confrontation of their mental attitudes and aesthetic positions. In order to achieve a dynamic equilibrium, tentatively speaking "aesthetic homeostasis" of positions, tastes, ideals that exist in the consciousness of modern society and the individual, it is necessary to know the prospects of development of the system of interrelations between the concepts of "mental attitude" and "system of the individual's aesthetic values" in the conditions of the modern social medium in the 10-ies of the new century.

\section{References}

Bassin, F.V., (1968). Problema bessoznatelnogo / o neosoznavaemykh formakh vysshey nervnoy deyatelnosti [The Problem of the Unconscious / about Unaware Forms of the Higher Nervous Activity] - Moscow: Meditsina, P.468 [in Russian]

Bochkarev, L.L., (1989). Psichologicheskie mekhanizmy muzykalnogo perezhivaniya [Psychological Mechanisms of Musical Experience]. Abstract of Doctoral Thesis. Psy. D. - Kyiv, P.44. [in Russian]

Bondyreva, S.K. \& Kolesov, D.V., (2007). Dukhovnost (psikhologiya, sotsiologiya, semantika) [Spirituality (psychology, sociology, semantics)] - Moscow: MPSI, P.144 [in Russian]

Bzhalava, I.T., (1969). Psikhologiya ustanovki I kibernetika [Psychology of Attitude and Cybernetics] - Moscow: Nauka, p.33

Dialektika poznaniya [Dialectics of Cognitions] / Karmin A.S. (Ed.). - Leningrad: LGU Press, (1988). - P.235. [in Russian]

Feldstein, D.I., (2005). Psykhologicheskoe razvitie cheloveka kak lichnosti [Psychological Development of a Person as a Personality]: Selected works: in 2 vols. Moscow: MPSI, - Vol.1., P.568, Vol.2. P.456. [in Russian]

Feldstein, D.I., (2012). Psykhologo-pedagogicheskaya nauka kak resurs razvitiya sovremennogo sotsiuma [Psychological-Pedagogical Science as a Resource of Development of Modern Socium] // Mir psykhologii. No.1., pp.204-220. [in Russian]

Kon, I.S., (1978). Otkrytie "Ya" [Discovery of "Self"]. Moscow: Politizdat, P.30 [in Russian]

Kon, I.S., (1987). Formirovanie lichnosti v perekhodnyy period: ot podrostkovogo $\mathrm{k}$ yunosheskomu vozrasty [Formation of Personality in the Transient Period: from the Puberty to Late Adolescence] / Edited by I.V. Dubrovina. - Moscow: Pedagogika, P.184. [in Russian]

Massovaya kultura I massovoye iskusstvo: Za I protiv [Mass culture and mass art: Pros and cons] (2003). - Moscow: Gumanitaryy. P.512. [in Russian]

Mozgot, V.G., (2012). The phenomenon of musical consciousness in a modern socio-cultural situation // Nauczyciel i Szkola №2 (52) Myslowice, p.p. 175-182.

Mozgot, V.G., (2009). Problema bessoznatelnogo v musykalnoy deyatelnosti i o Homo musicus [The Problem of the Unconscious in the Musical Activity and about Homo Musicus] // Mir psikhologii. No.3., p.p.261-272. [in Russian]

Mukhametzyanova, G.V., (2005). Professionalnoe obrazovanie: problem kachestva i nauchno-metoducheskogo obespecheniya [Vocational Education: Problems of Quality and Scientific-Methodical Provision] - Kazan: Magarif, P.319. [in Russian]

Prangishvili, A.S., (1967). Issledovaniya po psikhologii ustanovki [Psychology Attitude Research] - Tbilisi: Metsnierba, p.67 [in Russian]

Purvis, T., (2008). Media and Gender Socialization / In J. O'Brien (Ed.), Encyclopedia of gender and society. (pp. 534-541). Thousand Oaks, CA: SAGE Publications, Inc.

Simonov, P.V., (1985). Neosoznavaemoe psikhicheskoe: podsoznanie i sverkhsoznanie [The Unconscious Psychical: the subconscious and the superconscious]// In Kibernetika zhivogo: Chelovek v raznykh aspektakh [Cybernetics of the Alive: the Man in Various Aspects] - Moscow: Nauka, p.p.9-15. [in Russian]

Solbes, I., (2010). Explicit and implicit anti fat attitudes in children and their relationships with their body images / I. Solbes, I. Inesco // Obesity Facts. - Vol. 3., p.p. 23-32.

Tarasov, G.S., (1979). Problema dukhovnoi poterbnosti [The Problem of Spiritual Requirement]. - Moscow: Iskusstvo, P.191. [in Russian]

Tarasov, G.S., (1991). Psikhologiya muzykalnykh potrebnostei [Psychology of Musical Needs] - Abstract of Doctoral Thesis, Art.H.D., Moscow, P.47. [in Russian]

Uznadze, D.N., (1964). Obshchaya psikhologiya [General Psychology] - Tbilisi, p.92 [in Russian]

Uznadze, D.N., (1966). Psykhologicheskie issledovaniya [Psychological research] - Moscow: Nauka, P.348. [in Russian]

Uznadze, D.N., 2014. Filosofiya. Psikhologiya. Pedagogika: Nauka o psikhicheskoy zhizni [Psychology. Philosophy. Pedagogics: Mental Life Science]/Edited by I.V. Imedadze, R.T. Sakvarelidze. -Moscow: Smysl, - P.367. [in Russian]

Vartanova, I.I., (2007). Study of the Personality of Adolescents in Learning Activity / Russian Social Science Review. - Vol. 48. No.5. p.p. 47-56. 